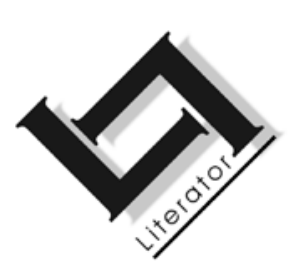

\title{
Metaphors of pain: the use of metaphors in trauma narrative with reference to Fugitive pieces
}

\section{J. Anker}

Faculty of Education \& Social Sciences

Cape Peninsula University of Technology

Wellington Campus

WELLINGTON

E-pos: ankerj@cput.ac.za

\section{Abstract \\ Metaphors of pain: the use of metaphors in trauma narrative with reference to Fugitive pieces}

This article is a contribution to the recent interdisciplinary discourse between psychoanalysis, trauma theory and narrative by discussing the traumatic experiences of characters in the novel "Fugitive pieces" by Anne Michaels, with a specific focus on the metaphorical style of this novel.

The article addresses the role of metaphor in the memory of trauma while comparing the relation between trauma, narrative and memory with reference to the work of Cathy Caruth, Van der Kolk and Margaret Wilkinson. Recent neurobiological research in the working of the brain during trauma and the insights of Borbelly in the role of metaphor during therapy are discussed.

Insights of Lacan, Modell and Laplanche are integrated with those of psychologists like Knox, Borbelly and Van der Hart to counter arguments against the criticism brought against some of the metaphorical themes in "Fugitive pieces".

Metaphor is seen as one possible way of saying the inexpressible and the progression in the use of metaphor by patient and character alike is seen as one of the signs of healing from trauma. 


\section{Opsomming}

\section{Metafore van pyn: die gebruik van metafore in die narratief van trauma met verwysing na Fugitive pieces}

Hierdie artikel is 'n bydrae tot die resente interdissiplinêre diskoers tussen die sielkunde, traumateorie en die letterkunde. Die roman, "Fugitive pieces" deur Anne Michaels, word bespreek met spesifieke verwysing na die gebruik van metafore om onder andere die belewing van trauma uit te beeld.

Die rol van die metafoor in die traumatiese geheue en die verband tussen trauma, die narratief en die herinnerings van die persoon betrokke word bespreek met verwysing na die teorie daaroor deur Cathy Caruth, Van der Kolk, Margaret Wilkinson en andere. Resente insigte van neurobiologiese navorsing oor die werking van die brein gedurende trauma en die insigte van Borbelly oor die rol van die metafoor in die traumatiese geheue word betrek.

Die metafoor word gesien as een van die wyses waarop die aanvanklik onverwoordbare traumatiese ervaring wel oorgedra kan word in die narratief van trauma.

\section{Introduction}

Reviews of Fugitive pieces (Michaels, 1996) repeatedly refer to the traumatic experiences of the main character, Jakob Beer, his references to these experiences in his autobiographical narration (part of his notes) and the metaphorical, even poetic, language of the text. The author, Ann Michaels, is a well-known Canadian poet.

The primal scene in Fugitive pieces that results in the trauma of Jakob Beer, a seven year-old child of Jewish parents, is the killing of his parents and the abduction of his sister, Bella, by the Nazis while he was hiding in the kitchen cupboard. The notes of his life thereafter form the basis of this novel.

In this article the belated description of Jacob Beer's traumatic experiences, the functions of the metaphorical style of this novel within trauma theory, and the role of metaphor in the memory of trauma is discussed. The article argues that the extensive use of metaphorical language in Fugitive pieces asks for another way of looking at it rather than only from the angle of literary interpretation. It is suggested that the reader could also interpret the use of metaphors from the perspective of the process of trauma, the narrative of trauma and the mind of the traumatised speaker, Jakob Beer, as narrator in this novel. 
As Cook (2000) and other reviewers of Fugitive pieces have given ample attention to the literary use of metaphors in this novel, I will emphasise the use of metaphor within the context of the traumatic experience in Fugitive pieces.

Kathryn Robson (2001:115-116) and Gerhard Werner's (2004:246) warning must be heeded that the interdisciplinary response that trauma has provoked in the last two decades, and the breakingdown of disciplinary boundaries, may result in an uncritical adoption of clinical models of trauma, assuming that these models are universally applicable and emphasise the so-called "narrative cure". Van der Merwe and Gobodo-Madikizela (2007:66) state that "Theorizing about trauma has to start with the premise that the phenomenon studied resists all theorization and defies an inclusive framework. And yet trauma cannot be simply ignored ..."

\section{Trauma}

Cathy Caruth (1996) who has written extensively on the relation between trauma, narrative and memory, defines trauma in a most general way as

a description of an overwhelming experience of sudden or/and catastrophic events in which the response to the event occurs in the often delayed, uncontrolled repetitive appearance of hallucinations and other intrusive phenomena ... trauma that is now often understood in the terms of the effects of posttraumatic stress disorder or PTSD (Caruth, 1996:11).

Margaret Wilkinson (2005) refers to Carl Jung's writings on traumatic experiences and his earlier perspective that the real traumatic events might disappear from the mind and be held only in the unconscious in the form of complexes. This dissociation as a result of trauma is defined by the American Psychiatric Association as, "a disruption in the usually integrated functions of consciousness, memory, identity or perception of the environment" (Wilkinson, 2005:484).

Wilkinson (2005:485) describes the findings of research on the effects of trauma on the functioning of the brain. She cites research by Teicher and Schore that has shown a reduction of connections between the right and left hemispheres of the brain through the effects of trauma, and the loss of connectivity within the right hemisphere of the brain where the major circuitry of regulation of emotion is placed. In therapy, these patients must be helped to integrate left and right hemispheres by linking past experiences with the present 
and by reworking and revisiting the emotional experiences that will eventually lead to coherent narratives (Wilkinson, 2005:486).

Traumatic experience affects both the encoding and recall of the memories associated with them. In the brain's response to severe trauma, sensations of feeling, behaviour, images and meaning become dissociated from one another (Wilkinson, 2005:487). As a result of this dissociation, there can be no "proper" memories of the event as they will not be processed by the hippocampus, which tags time and place to memories. As such, these experiences cannot be stored as explicit or narrative memory and will be encoded implicitly in the emotional brain and in the body, to remind and warn the victim when similar danger should threaten again (Wilkinson, 2005:487).

Van der Kolk $(2002: 384,385)$ discusses recent advances in neuroscientific research into brain images that have shown that during trauma the frontal areas of the brain, which are responsible for the analysis of experience and association thereof with other areas of knowledge, are deactivated. Deactivation of the dorsolateral prefrontal cortex interferes with the ability to formulate a measured response to threat. Trauma also interferes with Broca's area, the region of the brain necessary to put one's feeling into words. Combined with this decreased activity in Broca's area, there is an increased activation of the limbic system in the right hemisphere of the brain. Consequently, when people relive their trauma, they have great difficulty in putting the experience into words (Van der Kolk, 2002:387; Brewin, 2003:117-123; Peres et al., 2005:433).

Williams (2006:321) names symptoms of the body's self-defence mechanisms, such as dissociation, anxiety, depression and numbing. She also describes the so-called "belatedness" in trauma: "the quality of timelessness and time stopped in a victim's experience of that event" (Williams, 2006:322). The bodies and minds of traumatised people will react with freezing, numbing, detachment and forgetfulness when faced with similar danger or traumatic memories of the event (Williams, 2006:322). It is these memories that cannot be retrieved consciously that return in a fragmented form (flashbacks) and resist integration into the existing cognitive structures of the individual (Williams, 2006:323; Van der Kolk, 2002:383).

Karen Sealy (2005:22) also refers to the recurring nightmares, intrusive memories and emotional numbing, but stresses with other psychologists the fact that trauma is fully embodied, "it literally gets under the skin and is engraved in the brain" (Sealy, 2005:23). Traumatic events are also accompanied by other powerful emotions, 
such as sadness and loss, betrayal, humiliation and anger (Brewin, 2003:30).

Changing bodily functions are mentioned by Williams (2006:327) in referring to research by Van der Kolk, Kinniburgh and Perry that points to altered responses of the brain with an overdeveloped sensitisation to threats: "emotions become triggers of past trauma that are no longer clearly perceived". These disorganised sensations and patterns of activity, that result from the experience of helplessness and being frozen, are at the core of trauma. As Jakob Beer writes in Fugitive pieces: "It's a neurological disorder, I know what I must do but I can't move" (Michaels, 1996:148). According to Williams (2006) the beginning of the road leading away from trauma "is to name and tolerate sensations in the body. Finding words to explain a feeling is a step toward a personal narrative."

Language and metaphors are not only essential in the experience and description of trauma, but also in the process of healing. Finding words and formulating a narrative is a way of encoding trauma within the structure of language to bring order into the fragmented and splintered experience of the condition of trauma (Van der Merwe \& Goboda-Madikezela, 2007:15, 25, 26).

\section{The memory of trauma}

Van der Merwe and Gobodo-Madikizela (2007:6) emphasise that "extreme trauma leads to a loss of words because language is insufficient to describe the experience", and refer to Charlotte Delbo's identification of intellectual/external memory and deep memory: "Intellectual memory can be verbalized, ... deep memory cannot because language has been torn apart by trauma".

Psychologists differentiate between traumatic memory as emotional memory, implicit memory, deep memory, episodic memory and sensory memories; while referring to the normal historical memory as explicit, narrative, intellectual, external, and semantic. Brewin (2003:09-110) proposes a situationally accessible memory system (SAM) and a verbally accessible memory system (VAM).

Much has been written about traumatic memory. Wilkinson (2003: 238-239) describes the process as follows:

... if the frantic distress associated with trauma takes its toll, and flight or fight is perceived to be impossible, hopelessness supervenes and the limbic system command the freeze reaction. The parasympathetic nervous system takes over and 
inhibits activity ... It is then that disengagement and dissociation of both mind and body occur. Such traumatic experience becomes encoded in implicit memory, unavailable to the conscious mind.

Flashbacks as a way in which trauma-induced memory may be evoked, resulting in a "highly aversive motivational state of terror and helplessness" are described by Wilkinson (2003:239). Research even points to a loss of cell volume in the hippocampus and a resultant loss of memory in trauma patients (Wilkinson, 2003:239). Other research has commented that the memory representations of the traumatic event can be triggered at any time and be relived by the patient in the most painful and terrifying way - in Jung's words: "it pounces upon him like an enemy or a wild animal" (Wilkinson, 2003:240).

Kaminer (2006:484) refers to a body of literature that indicates that narrative memory, our understanding and organisation of the past, is disrupted by a traumatic experience which resists assimilation into the narrative memory. Instead, it is relived through intrusive thoughts, nightmares, flashbacks and hallucinations. Traumatic memories are the unassimilated scraps of overwhelming experiences which need to be transformed into narrative language: "traumatic memories, unlike other emotionally charged memories, are retrieved as sensory fragments with no verbal component". Van der Kolk and Van der Hart (1995:167) states that this trauma is relived repeatedly until a person is able to remember simultaneously the affect and cognition associated with the trauma through access to language. Jakob refers to his "daydreams of sickening repetition" (Michaels, 1996:25).

Caruth (1995:8) also emphasises the "timelessness" and "placelessness" in the peculiar temporal structure of trauma and the link with repetition: "the belatedness of historical experience: since the traumatic event is not experienced as it occurs, it is fully evident only in connection with another place, another time".

In discussing Freud's Beyond the pleasure principle, Caruth (1996: 2) refers to the original meaning of the word trauma, namely wound. She describes trauma as a double wound that could not be assimilated into the conscious when it happened and haunts the survivor afterwards:

$\ldots$ it is always the story of the wound that cries out, that addresses us in the attempt to tell us of a reality or truth that is not otherwise available. The truth in its delayed appearance 
and its belated address, cannot be linked only to what is known, but also to what remains unknown in our very action and our language. (Caruth, 1996:4.)

The story of trauma, according to Caruth (1996:7) is always two stories: "a double telling ... the oscillation ... between the story of the unbearable nature of an event and the story of the unbearable nature of its survival".

In an interview with Caruth, Jean Laplanche also mentions Freud's theory that trauma consists of two moments, "the experience of something coming from outside, or the memory of it, that must be 'reinvested' in the second moment and then it becomes traumatic it is the second reliving and memory that becomes traumatic, not the first act" (Caruth, 2001:2). This belatedness or Nachtrachlichkeit as Freud called it, is the belated effect of the traumatising event. According to Greg Forter (2007:264) trauma is the psychic result of knowledge that comes at once too soon and too late. The "primal scene" as Freud referred to it, is the scene around which the unassimilated memories coalesced that will come to traumatise the individual later.

In Fugitive pieces it becomes a refrain: "Every moment is two moments" (Michaels, 1996:138).

\section{Metaphors and trauma}

Modell (2005) refers to this retroactive experience of trauma as the recontextualisation of the earlier memory and the defence mechanism of repression or displacement of the subsequent emotions and feelings. He then goes on to name this "symbolic or metaphorical displacement" as part of the defence mechanism and states that metaphors function unconsciously as a "pattern detector" for psychoanalysts who may use metaphorical similarities as a means of interpreting emotional memory (Modell, 2005:560). Wilkinson (2003: $247 ; 2005: 492)$ agrees that the role of metaphor is that of facilitating the emergence of memory because of its power to re-establish the integrated working together of the two hemispheres of the brain after trauma. In the therapeutic process it is important to recognise that metaphors are believed to activate multiple brain centres simultaneously. Brewin (2003:112) also refers to studies that agree with the view that memory exists in two forms, one in the perceptual (imagery) code and one in the verbal code. 
As Borbelly (1998) has written specifically about the psychoanalytic concept of metaphor, I will summarise his arguments in more detail. He defines metaphor according to Ricoeur: "Metaphor can be defined in its simplest terms as seeing something in terms of something else"; and Kittay (Borbelly, 1998:923):

Metaphor provides the linguistic realization for the cognitive activity by which a speaker makes use of one linguistically articulated domain, to gain an understanding of another experimental or conceptual domain, and similarly, by which a hearer grasps such an understanding.

According to him it is the role and function of metaphor to deal directly with the transformation and creation of new categories (Borbelly, 1998:923) by functioning as a structure that establishes a "mapping of knowledge from one domain to another" (Borbelly, 1998:926).

He argues that trauma leads to a degradation of metaphorical processes to mere analogic ones which relates to the repetition compulsion. He believes that the re-establishment of metaphorical connections between the developmental events (past and present) and transference events will lead to the re-establishment of creativity (Borbelly, 1998:924). In psychoanalysis, he says,

... symptoms can be seen as entailing re-enactments of past experiences that remained without the benefit of new class inclusions from subsequent experiences. The conceptual categories within which these past experiences were understood remained frozen, awaiting metaphorical enrichment through interpretation and insight. (Borbelly, 1998:926.)

Borbelly (1998:930) states that trauma reduces the polysemy of images of experience due to overwhelming anxiety, and leads to a fixed meaning of the experience - elements of meaning are frozen in unchanging relationships (cf. also Modell, 2005:562) which surface in the repetition compulsion. He sees the process of symbol formation as a continuous process of bringing together and integrating the internal with the external, subject with object, earlier experiences with later ones: "Through symbol formation and metaphor that is one of our most important tools for trying to comprehend partially what cannot be comprehended totally. ... The meaning not known and feared is gradually revealed ..." (Borbelly, 1998:933; Schwager, 2004:375, 378). Delbo, quoted by Van der Merwe and Gobodo-Madikizela (2007:67), talks about a language split in two. 
Words used in everyday communication become a reference to a radically different experience.

Ellie Ragland (2001) also refers to the frozen metaphors when she discusses Lacan's interpretation of Freud's Beyond the pleasure principle in an article entitled "The psychical nature of trauma". According to Lacan, what has been repressed, the inexpressible and unspeakable, will return in the symbolic order of language (Ragland, 2001:1) and this symbol will be a realistic one (Ragland, 2001:6). The function of metaphor in this regard, is that it "produces a condensation as it allows one to make equivalency relations, to substitute one thing for another in a secondary process way, because the substitute element already has a referent" (Ragland, 2001:9), it is not an effect that is repressed. What are repressed "are the signifiers that anchor it and become frozen metaphors" (Ragland, 2001: 11).

A repressed, metaphorical subject is, according to Lacan a connector, a limit point to memory and representation, a denotation for what remains of an object that has been lost in the first place. This object is the person's only knowledge of a lost subject that surfaces as "some unitary trait, some memory whisp, some stark image" (Ragland, 2001:13). As Jakob Beer formulates it in Fugitive pieces: denotation remains denotation (Michaels, 1996:143). The "transference metaphor" in trauma establishes only similarities in a rigid way, a compulsive need to force a similarity between the past and the present (Modell, 2005:562). Modell (2005:565) accordingly sees episodic memory as emotional memory whose activation is triggered by metaphorical similarities between past and present.

Williams (2006:330) emphasises the role of metaphor in the healing process of trauma by referring to the creative processes that are found "in the transformation of metaphor, symbols and patterns in words and visualizations". Telling the story through new perspectives provides the change to assign meaning, integrate the experience, find recognition and relive events. Kaminer (2006:486) also refers to brain research about trauma patients that suggests that the failure of traumatic memories is linguistically based.

LaCapra (2001:186) refers to post-traumatic writing, which involves the processes of working over and acting out, analysing and "giving voice" to the past. In this sense even the present and the past can be seen as metaphorical, as the present is understood in terms of the past and vice versa (Borbelly, 1998:925; Modell, 2005:562). 
It is precisely the aim of these repetitions of metaphors, images and visualisations in the recurring memory of a trauma patient to reconstitute itself as a being of consistency, recognition and unity against the traumatic experience of the lack of the subject (Ragland, 2001: 13). During repetition compulsions metaphor is only a form, not a creative metaphor that leads to new perspectives and new categories in a new domain (Borbelly, 1998:972). These creative metaphors, that may develop later, have the power to re-establish the integrated working-together of the two hemispheres of the brain after trauma (Wilkinson, 2005:562). They become the "associative glue". It is in the slow evolution of symbolic metaphors that severe trauma may be healed: "Survivors of trauma can often find meaning more easily in objects, and respond to images and to music to help them to start to find words to speak the unspeakable" (Alcock, 2003:303).

This integration and blending of the past and present, image and reality lead to a synthesis of trauma, "the memory ceases to be reexperienced in a traumatic way. The trauma becomes a 'neutral' historical fact". This is called the process of realisation; the patient integrates the experience as part of his/her life history, the narrative memory (Van der Hart et al., 1993:6). Peres et al. (2005:434) makes the important observation that the retrieval of traumatic memories is within an altered state of consciousness and once the state of consciousness shifts, the perception of the same event will also change. Telling the story is an important component of this realisation and integration: "words begin to allow the patient to form new semantic structures that will assist him or her to assimilate the trauma over time" (Van der Hart et al., 1993:13), or as Borbelly (1998:933) stated it: "The meaning not known and feared is gradually revealed".

\section{Fugitive pieces and metaphor}

Meira Cook's article "At the membrane of language and silence" describes Fugitive pieces as "densely metaphoric" (Cook, 2000:12) and the "sustained exploration of memory, represented through imagery and metaphor" (Cook, 2000:13). She and other reviewers like Bentley (1999) and Gubar (2002) refer to the primal trauma of Jakob Beer, a traumatised subject whose being has been split and dissociated. Trauma and guilt are the driving forces behind his character. Symptoms like amnesia, recurring dreams and the return of suppressed memories are named (Cook, 2000:15) and she also refers to this kind of text as a post-traumatic narrative (Cook, 2000: 20). 
Cook (2000:24) describes Michaels' metaphorical style as using metaphor to "articulate the trauma of history in language that is itself in crisis ... to tell a story that is irreconcilable with words because unbearable". Cook also refers to the "compulsive metaphorization" as a function of the narrative of trauma and to metaphors that "conceal meaning and transforms it" (Cook, 2000:24).

Cook also voices some concerns about the dense metaphorical text, although she has very high praise for the sometimes brilliant use of metaphors. Cook is concerned about the paradoxical "lush poetic discourse" against "the horror she is narrating", a "flatness that results" when using the same metaphors for unnamable brutality and love-making (Cook, 2000:16) so that, in her mind, sometimes "metaphorical language is used indiscriminately" (Cook, 2000:17) and even sometimes seems "contrivial" (Cook, 2000:18).

As stated earlier, the extensive use of metaphorical language in Fugitive pieces asks for another way of looking at it than only from the angle of literary interpretation. The theory of trauma and the role of metaphor in trauma suggests that in the attempt to describe the indescribable and unrepresentable in a literary text, metaphors may be used as literary, poetic metaphors, but also to describe the traumatic experience, the memory of trauma and the healing process of trauma.

Having stated this, the metaphors in Fugitive pieces should also be read in the context of a poet, Jakob Beer, writing his autobiographical notes, within a novel written by a poet, Anne Micheals! As readers we may naturally be interpreting metaphors within their full (polysemic) sense, while the character may use them in the context of a flashing reality from a fragmented memory. This paradoxical state will remain one of the tensions within the reading of this novel. It is indeed a "sustained exploration" (Cook, 2000:13) of a metaphorical knot.

I will emphasise the use of metaphor within the context of the traumatic experience in Fugitive pieces.

\subsection{Metaphors of the traumatic experience}

Bearing in mind the etymology of the word trauma, meaning open wound, as metaphor for the experience of physical and emotional pain, the title, Fugitive pieces, opens the novel with a metaphorical reference to pieces of memory, fragments of evidence and flashbacks of reality. At the same time the traumatic history is pictured as 
something that is hidden, concealed and contaminated in the form of hidden manuscripts and lost artifacts. The description of realistic, historical events becomes metaphorical of a personal and collective trauma. Michaels refers to these metaphors as very deep metaphors: "there is a sense of time, of consequence, of accumulation ... They're not metaphors of abstraction. They're metaphors of reality, taken from reality" (Cho, 1996).

The gaps in memory and history as part of the amnesia, shock and effect of trauma are presented through metaphor by silences after the primal trauma and the dissociation thereafter (Van der Kolk, 2002:385, 387). The story must be told by Jakob, "a blind man, a prisoner of sound" (p. 17); ${ }^{1}$ he is filled with "Bella's silence" (p. 10) and this indescribable silence can ironically/paradoxically only be recovered by a remembrance of fragmented sounds: a door breaking, a piano playing ...

The language that must be found to represent the inexpressible becomes a foreign language, a language without memory, at a distance, a play with forms, only a translation of a lost reality, forgotten lullabies, an "alphabet without memory" (p. 101).

Even in the reference to time, the traumatic experience becomes a metaphor in the use of the present experience: filled with memories of an uncompleted past "every moment is two moments" (p. 143), which also represents the split between the present experience and the still unintegrated past: it remains the "gradual instant". Borbelly (1998:933) has formulated this process likewise: "The meaning not known and feared is gradually revealed". The continuous digging in and reliving of the past are represented by the references to burials, excavations, archaeology and limestone. The remembrance of and repeated reference to drowned cities also link with the concept of a buried past.

In writing down these experiences, the gradual forming of the unitary narrative emerges. Athos says, "write to save yourself". Thus, the process of writing and the formation of meaning are emphasised by numerous references to manuscripts, lost narratives, diaries, memoirs, eyewitness accounts, poems and a number of characters who are storytellers. 
The bodily experience of trauma is conveyed by, inter alia, the descriptions of the skin: the thin membrane of the eardrum through which the sounds must be heard; memory is "transmitted through the blood" (p. 52), over the boundary of the skin (he enters) "into Michaela's memories" (p. 185). As Wilkinson (2003:242) describes it: "The body is the theatre ..., the body speaks ..., the body remembers ..., and the body keeps the score ..."

\subsection{Metaphors of memory}

A long list of repeated metaphors of memory points to a fragmented memory and the recurring effort to complete the uncompleted, visualise the unseen, through concrete, realistic images. As Modell states (2005:562):

In these displacements, the individual experiences a more rigid rift between the present and the past, a compulsive need to force a similarity between the past and the present.

Cook (2000:13) emphasises the importance of memory in Fugitive pieces and names the fragility of memory (a characteristic of trauma) symbolised by the loss and burial of "countless manuscripts, diaries, memoirs, eye-witness accounts" - narratives that are hidden or buried and must be retrieved gradually by the victim or witness a process presented by the repeated reference to digging, excavating, archaeological activities, the formation of limestone, buried cities, silted rivers and sedimentary rock.

Memories are also referred to as contaminated: entering through the pores of the SS, digging up mass graves (p. 52), and becoming parasitical: "the dead entered through their pores and were carried through their bloodstreams to their brains and hearts. And through their blood into another generation" (p. 52) (Cook, 2000:18). The impossibility to verbalise these memories is stated: "My life could not be stored in any language but only in silence" (p. 111).

The narrator expresses the realities he experiences as encoded in the reality around him: "encoded in air currents and river sediment" (p. 53). At the same time he experiences the recurring memory of grief and trauma as never-ending: "How many centuries before the spirit forgets the body?" and as a result the memory of grief remains inside: "Grief requires time" (p. 54). The screams of all the victims are carved into far-off galaxies until the starlight that reaches us is "only the white breath of an old cry". 
The male characters of Fugitive pieces return to their places of memory, places of origin: Zakintos, Odessa, Idhra, but the effort does not heal them. As in the memory of trauma the images and reality are never the same, memories are never quite completed, they only remain part of the memory and narrative that must still be completed. Kaminer (2006:486) refers to this state as the process whereby the victim of trauma struggles "to organize his memory fragments into sequential episodes".

The memory of trauma as something to be grasped beneath the surface of consciousness is metaphorically represented by repeated reference to archaeology, drowned cities, a repeated rebirth (p. 5, 14), bodily experienced "like bruises" (p. 19), part of a ghostly history, a bridge between present and past, a double exposure (p. 18), but also partly amnesiac (language without memory). It must be excavated from beneath the "crushed reef of memory, the living stone" (p. 32), it is a water stain on a map and the rings in trees (p. 137). From behind the dissociative barrier the memory and the suffering must be released (Wilkinson, 2003:243).

The memory of trauma remains buried in the unattainable unconscious and the variety of references to burials and rebirths emphasises the effort to see through the "lid of the earth" (p. 206), to see, to understand, to grasp something of the ever-eluding truth, that will forever be lost (Cook, 2000:27). Even language itself, the language of trauma "annihilates metaphor": denotations remain only denotations (p. 143).

\subsection{Metaphors of healing}

Jakob's first sense of being a false witness, because of a "false" memory, is after Athos' death, when he returns to the "familiar drug: the history of matter" (p. 119) and he states that he is "bearing false witness" because "murder (trauma) steals from a man" (p. 120). Although Alex is his first "sense of freedom" (p. 130), this "finger of light" in his dark, depressing world remains as "cold as bone" (p. 139). The world of language with which Alex bombards him, is not sufficient. He writes short stories of hiding (p. 130), his nightmares are returning and he cannot differentiate between Alex and Bella, present and past; he has met Alex while looking for Bella in music (p. 127). He is still caught in memories of trauma that are "maps of history" that "have always been less honest", where terra cognita and terra incognita remain the same (p. 137), the "hundred accumulated fragments" of history and memory are still only one incomprehensible long story (p. 138). 
In this experience time always represents both past and present and he is incapable of distinguishing between the two: "Every moment is two moments" becomes the refrain (p. 138, 140, 143, 161) and he remains caught in the memory of the past and the present conscience: "what we consciously remember is what our conscience remembers" (p. 138). Grief and death are entwined in one bodily metaphor: "A mother felt the weight of her child" (p. 138, 155) and Alex's body is associated with the deaths of camp inmates: wooden bunks, breathing bones, a cold wooden bunk (p. 141). Objects become past and present, Alex and Bella are both associated with a hairbrush (p. 140). During his lovemaking with Alex, Bella knocks on the wall (p. 146). Jakob remains focused on the moment of trauma, the "historical split second, the tableau of the haunting trinity, "perpetrator, victim, witness" (p. 140) and he is still caught in the "anguish of the moment of death" (p. 140). He realises he will remain there until he can give Bella's "death a place" (p. 139). That event can only become meaningful when "the coordinates of time and place are witnessed" (p. 161) - when the past is integrated in the present narrative memory. Doomed to repeat only the past, he knows (p. 161), he still recognises the "duplicity of history" (p. 161), where buried underneath the ground, the silent absence, something may grow out of the "compost of history" (p. 161).

From language that annihilates metaphor, he now feels that his English is "strong enough to carry this experience" (p. 162), that at last he has found a language that "surrenders to what it is describing". While the poems that he was writing before he returned to Idhra are described as "ghost stories" and even when he is there, he is only trying to "embroider darkness" (p. 164). Eventually it is from the "lowest point of degradation" (p. 167), imagining Bella through photos of victims as part of the "pyramids of flesh" in the camps, "her skin coming apart" (p. 167), that he returns to faith and grace: "At the moment of utmost degradation, in that twisted reef, is the most obscene treatment of grace".

In that moment of insight the language of darkness and death changes to light: "In the still house, the visitation of moonlight. It occupies the darkness" (p. 168). When he recognises that his brokenness has kept her (Bella) broken (p. 169), the sky is transformed into glass (p. 169). Van der Hart et al. (1993:14) refer to the changing narrative and the semantic aspects of the traumatic event. These often involve reframing the patient's own interpretations.

In the past, the two languages, Hebrew and Greek, could only carry absence (p. 169) and his body only remembered the dead. He did 
not hear that they wished him to be back in the world (p. 170). At this moment, the "gradual instant", the slow process of healing, starts to overcome the experience that every moment is two moments.

At this moment, when the memories of the traumatic past begin to integrate with the present, the metaphors change. The frozen metaphors of trauma, darkness and death, buried history and memory, lost generations and deathly silences become open and light. Schwager (2004:350) explains this process: "In feeling that inner freedom to reflect ... allows for the transformation of the metaphor of terror to the metaphor of being alive".

When he meets Michaela, he is open to a new experience of love, even the space around him changes from images of caves and shadows to her mind is a "palace". The street is a "theatre of whiteness" (p. 176), the leaves are "dripping silver" (p. 180), images of light abound (p. 182, 190); stillness and silence change - not something broken anymore, but rest (p. 181). Silence becomes the "response for both emptiness and fullness" (p. 194) - even the nights are there to heal (p. 183), nights of happiness (p. 194). He is aware of sounds of joy, sounds even become colours (p. 184). No signal is taken for granted anymore - denotation becomes connotation. Metaphors become polysemic instead of frozen fragments of a traumatic memory (Borbelly, 1998:931).

The metaphors of body and burial also change: "Instead of the dead inhaling my breath with their closeness, I am deafened by the buzzing drone of Michaela's body" (p. 180), he is being dug out and "lifted into the world" (p. 182), he experiences the "power lines of blood", (not the previous parasite!), for the first time he feels safe above ground (p. 189). Now death "for the first time makes me believe in the body" (p. 189), he is saved by Michaela's small body (p. 183), he crosses over her boundary of skin (p. 185) when loving her - the fugitive pieces of a fragmented memory can change to the fugitive scents of her loveable body (p. 191).

It becomes possible to have happy memories (p. 192). He lives in the present: "She looks at me, all presence" (p. 191). He remembers Bella without fear (p. 191), he misses them, but there are no absences (p. 193). Now he can start mapping his thoughts into a conscious memory: "If one no longer has land, but has the memory of land, one can make a map" (p. 193). 
Where he was once lost in a forest with only the two syllables of Bella's name onto which to hold (p. 195), he experiences freedom in the birch forest: "I slip free the knot and float, suspended in the present ..." (p. 188). In that forest he feels safe for the first time (p. 189). It is a gradual release, a process of integration, the gradual instant: "Happiness is wild and arbitrary, but it is not sudden", like trauma (p. 184).

The second part of the novel duplicates processes and metaphors as a parallel experience from the perspective of a next generation of trauma survivors, Jakob's heir, Ben, the child of Holocaust survivors. In Ben's case his parents did not find the narrative cure: "There was no energy of a narrative in my family" (p. 204), only "a code of silence" (p. 223) and evidence of frozen metaphors like the "Ess Ess" (p. 225).

In contrast, affirmation of Jakob's healing process is found in the reference to changed metaphors in his life: "a man who claimed to believe so completely in language" (p. 207); someone who reached "the pure state of residual concentration" (p. 207); a man who used an open, ambiguous metaphor like: "electron ... a dissonance like grief, whose pain is love" (p. 211). In reference to Jakob's poems, there is the final summary of his healing:

Your poems from those few years with Michaela, poems of a man who feels, for the first time, a future.Your words and your life no longer separate, after decades of hiding in your skin. (p. 267).

In the case of Jakob Beer the process of integration of past and present, "the integrity and trust in caretaking relationships revives the sense of human bonding" (Williams, 2006:326). The sensory fragmented memory is "translated into a declarative (emotional) memory $\ldots$ the self growing dialogue triggered the construction of a resilient behaviour" (Peres et al., 2005:441, 443).

\section{Conclusion}

During this study it has become evident that the use of metaphors in Fugitive pieces can be seen as multifunctional: as literary metaphors, as leitmotivs in the novel, as metaphors for the traumatic experience and traumatic memory, as signifying the traumatic state of mind of the narrator, as metaphors of the healing process, as a foreign, distanced language to give words and images to an indescribable experience. 
From the viewpoint of trauma theory and the importance of metaphorical processes in the experience and memory of trauma, it is clear that some metaphors can be described as frozen images with analogical, unchanging relationships. Gradually some of these frozen metaphors of trauma change to metaphors of healing. The silence of absence and death becomes a referent for emptiness and fullness; language without memory becomes a language that can describe the traumatic experience; the hidden limestone becomes the pure state of integrated memories; the skin through which the parasite of death intrudes, becomes the touch of love. No signal is taken for granted anymore, denotation turns to connotation, meaning is open to a new mind.

Jacob Beer has had to go back to the beginning of language to discover a new language in which "the splits between acts and words, vocalization and verbalization, affective meanings and semantic meanings, sexuality and tenderness can be finally healed" (Connolly, 2002:377). These metaphors indicate the change from frozen metaphors to more creative metaphors in the process of integration and realisation as part of the transference process wherein the individual can reconstitute himself.

The metaphorical process is also part of the formation of a coherent trauma narrative, the post-traumatic work-over to integrate past and present in the explicit, narrative memory. It is sometimes in "the perversion of metaphor" (Felman, 1995:36) that the inexpressible becomes sayable. It is the creative symbolic process of creating poetry (read: metaphor) that "has the most power to heal and stand up against genocidal forces" (Schwager, 2004:368). In the words of Athos to Jakob: "Write to save yourself ... and someday you'll write because you've been saved" (p. 165).

\section{List of references}

ALCOCK, M. 2003. Refugee trauma: the assault on meaning. Psychodynamic practice, 9(3):291-306.

BENTLY, D. 1999. Anne Michael's Fugitive pieces. Canadian poetry, 41:5-20.

BORBELLY, A.F. 1998. Psychoanalytic concept of metaphor. The international journal of psychoanalysis, 79:923-936.

BREWIN, C.R. 2003. Post-traumatic stress disorder. Michigan: Vail-Ballou.

CARUTH, C., ed. 1995. Trauma: explorations in memory. London: Johns Hopkins University Press.

CARUTH, C. 1996. Unclaimed experience: trauma, narrative and history. Baltimore: Johns Hopkins University Press.

CARUTH, C. 2001. An interview with Jean Laplanche. http://www3.iath.virginia. edu/pmc/text-only/issue.101.2caruth.txt. Date of access: 26 Oct. 2007. 
CHO, C. 1996. Interview with Anne Michaels. Ubyssey: 8 Nov. http://www.3.telus.net/ccho/michaels.html Date of access: 17 Mar. 2006.

CONOLLY, A. 2002. To speak in tongues: language, diversity and psychoanalysis. Journal of analytical psychology, 47:359-382.

COOK, M. 2000. At the membrane of language and silence: metaphor as memory in Fugitive pieces. Canadian literature, 164:12-23.

FELMAN, S. 1995. Education and crisis, or the vicissitudes of teaching. (In Caruth, C. ed. Trauma: explorations in memory. London: Johns Hopkins University Press. p. 13-60.)

FORTER, G. 2007. Freud, Faulkner, Caruth: trauma and the politics of literary form. Narrative, 15(3):259-285.

GUBAR, S. 2002. Emphatic identification in Anne Michaels's Fugitive pieces: masculinity and poetry after Auschwitz. Signs: 249-275, Autumn.

KAMINER, D. 2006. Healing processes in trauma narratives: a review. South African journal of psychology, 36(3):481-499.

LACAPRA, D. 2001. Trauma, absence, loss. Critical inquiry, 25:696-727.

MICHAELS, A. 1996. Fugitive pieces. London: Bloomsbury.

MODELL, A.H. 2005. Emotional memory, metaphor, and meaning. Psychoanalytic inquiry, 25:555-568i.

PERES, J., MERCANTE, J. \& NASELLO, G. 2005. Psychological dynamics affecting traumatic memories: implications in psychotherapy. Psychology and psychotherapy: theory, research and practice, 78:431-447.

RAGLAND, E. 2001. The psychical nature of trauma: Freud's Dora: the young homosexual woman, and the fort! da! paradigm. http://www.3iath. virginia.edu/pmc/text-only/issue.101/11.2ragland.text Date of access: 12 Nov. 2006.

ROBSON, K. 2001. Curative fictions: the "narrative cure" in Judith Herman's trauma and recovery and Chantal Chawaf's Le manteau noir. Cultural values, 5(1):15-130, Jan.

SCHWAGER, E. 2004. Transforming dualism and the metaphor of terror. Part 1: From genocidal to dialogic mentality: an intergenerational struggle. Psychoanalytic review, 91(3):347-394.

SEALY, K. 2005. Trauma as a metaphor: the politics of psychotherapy after September 11. Psychotherapy and politics international, 3(1):17-27.

VAN DER HART, O., STEELY, C., BOON, S. \& BROWN, P. 1993. The treatment of traumatic memories: synthesis, realization, \& integration. Dissociation, 6(2/3):162-180. http://www.-trauma-pages.com/a/vdhart93.php (1-25) Date of access: 2 Nov. 2007.

VAN DER KOLK, B.A. 2002. Posttraumatic therapy in the age of neuroscience. Psychoanalytic dialogues, 12(3):381-392.

VAN DER KOLK, B.A. \& VAN DER HART, O. 1995. The intrusive past: the flexibility of memory and the engraving of trauma. (In Caruth, C., ed. Trauma: explorations in memory. London: Johns Hopkins University Press. p. 158-182.)

VAN DER MERWE, C. \& GODOBO-MADIKEZELA, G. 2007. Narrating our healing: perspectives on working through trauma. Newcastle: Cambridge Scholars Press.

WERNER, G. 2004. Siren call of metaphor: subverting the proper taste of neuroscience. Journal of integrative neuroscience, 3(3):245-252.

WILKINSON, M. 2003. Undoing trauma: contemporary neuroscience. Journal of analytical psychology, 48:235-253. 
WILKINSON, M. 2005. Undoing dissociation: affective neuroscience: a contemporary Jungian clinical perspective. Journal of analytical psychology, 50:483-501.

WILLIAMS, W.I. 2006. Complex trauma: approaches to theory and treatment. Journal of loss and trauma, 11:321-335.

\section{Key concepts:}

\section{healing}

metaphor

trauma: memory

trauma: theory

\section{Kernbegrippe:}

heling metafoor

trauma: geheue

trauma: teorie 